\title{
Phytonematode Community Structure and Dynamics on Ornamental Plantations of Egypt
}

\author{
Al-Sayed A. Al-Sayed, Abdullah A. Abdel-Rahman and Hosny H. Kesba
}

Zoology and Agricultural Nematology Department, Faculty of Agriculture, Cairo University

\section{Abstract}

In a survey study, 21 phytonematode genera, Aphelenchoides, Criconemoides, Brachydorus, Criconema, Ditylenchus, Helicotylenchus, Hemicriconemoides, Hemicycliophora, Heterodera, Hoplolaimus, Longidorus, Meloidogyne, Paratylenchus, Pratylenchus, Rotylenchulus, Scutellonema, Tetylenchus, Tylenchorhyncus, Tylenchulus, Tylenchus and Xiphinema were found infesting rhizosphere of ornamental plantations in 5 Egyptian governorates. As the soil lighten, the nematode genera thrive, populate and diverse. Helicotylenchus, Hoplolaimus and Paratylenchus were recorded in high abundance and density in peat samples. The surveyed perennials were poor in their infestation. Helicotylenchus, Rotylenchulus, Tylenchorhynchus and Tetylenchus were in common association with the ornamental trees (Italian cypress, Ficus and Flamboyant). Nematode genera abundance and density were variable in shrubs. Paspalum samples infested with 15 out of the recorded 21 genera.

Dynamics of Criconemoides, Helicotylenchus, Hoplolaimus and Rotylenchulus on four shrubs (Schefflera, Windoleaf, Dodonea, Lantana) grow in clay loam soil indicate that nematodes achieved high and low seasonal patterns depending on soil temperature, host plant, nematode species and nature of nematode parasitism.

Keywords: Ornamentals, Nematodes, Survey, Dynamics.

\section{Introduction}

Economic importance of ornamental plants is increasing in Egypt. Egypt's exports values of ornamental and cut flowers was estimated by EGP 350 million (Ministry of Agriculture, 2013). Ornamental and flower culture plantations are severely infested with several stylet bearing nematode genera. Criconemoides, Tylenchorhynchus, Rotylenchulus, Pratylenchus, Paratylenchus, Helicotylenchus, Heterodera, Xiphinema, Longidorus, Hoplolaimus, Ditylenchus, Criconemella and Aphelenchoides were found infesting rhizosphere of carnation, roses, flower bulbs, chrysanthemum (Streu et al., 1961; Kim et al., 1987; Nagesh and Reddy 1996; Khanna et al., 1997 and Singh and Sharma 1998).

The knotting nematode species, Meloidogyne incognita, M. javanica and $M$. arenaria were identified infecting carnation, chrysanthemum, gladiolus, tulip, narcissus and snapdragon (Kinshakova, 1968; Sen and Dasgupta, 1977; 
Brezeski et al., 1979; Saka and Siddiqi, 1979; Nagesh and Reddy 1996; Tenete, 1996; Jagridar, 2005, Singh and Sharma, 1998; Deimi et al., 2008; Brito et al., 2010 and El-Sherbiny, 2011).

The seasonal effects on the population dynamics of plant parasitic nematodes have been extensively studied on different hosts. The multivariate structure in nematode community is depending on many edaphic and biotic factors, temperatures, soil type, soil moisture, soil depth, $\mathrm{pH}$, organic substance, rainfall, host type and cultivar compatibility, microflora, microfauna, host root distribution and even the interrelationships between two or more of these factors (Al-Sayed, 1983; Kesba, 1999; Neher et al., 2004; McGroary 2009; Renco et al., 2010 and Gantait and Bhattacharya, 2013).

The objective of this study was to:

1. Define and document the abundance and density of plant parasitic nematodes associated with some ornamentals.

2. Study the phytonematode community structure and dynamics on ornamental shrubs.

\section{Materials and Methods}

\section{Survey, nematode numeration and identification:}

Nine hundreds and nine soil and root samples were collected for nematode analysis from different Egyptian governorates (Beheira, Cairo, Giza, Qalyubia and Sharqia) growing fifteen ornamental plant species (Table 1). Each sample was composite of two subsamples obtained from plant rhizosphere at $0-15 \mathrm{~cm}$ depth. All samples were kept in polyethylene bags labeled and sent to laboratory for nematode extraction, identification and numeration.

Modifies Cobb's sieving and Baermann funnel technique (Hooper et al., 2005) was followed by using a series of sieves for nematode extraction from soil. The suspension containing nematodes was then poured gently over a double layered tissue paper placed over plastic dishes. After $48 \mathrm{hr}$ the nematode suspension was collected and examined under a stereoscopic binocular microscope. The nematode genera were tentatively identified by comparing the characters given by Mai and Lyon (1975). They were confirmed by making semipermanent and permanent slides.

The population densities of different nematode genera in the samples were calculated using the formulae (Norton, 1978):

$$
\begin{aligned}
& \text { Absolute density }=\frac{\text { Number of individuals of a species in a sample }}{\text { Volume or mass or units of the sample }} \times 100 \\
& \text { Relative frequency }=\frac{\text { Frequency of a species }}{\text { Sum of frequencies of all spp. }} \times 100
\end{aligned}
$$


Absolute frequency $=\frac{\text { Number of samples containing a species }}{\text { Number of samples collected }} \times 100$

Table (1): Scientific, common and arabic names of surveyed ornamental plants.

\begin{tabular}{|c|c|c|c|}
\hline Plant group & Scientific name* & Common name & Arabic name \\
\hline Lawns & $\begin{array}{l}\text { Paspalum vaginatum } \\
\text { Chrysanthemum morifolium }\end{array}$ & $\begin{array}{l}\text { Paspalum } 10 \\
\text { Chrysanthemum }\end{array}$ & نجيل بسبالم \\
\hline Perennials & $\begin{array}{l}\text { Epipremnum aureum } \\
\text { Solidago sp. }\end{array}$ & $\begin{array}{l}\text { Pothos } \\
\text { Goldenrod }\end{array}$ & السيليداجو البو \\
\hline Shrubs & $\begin{array}{l}\text { Aralia spinosa } \\
\text { Codiaeum variegatum } \\
\text { Cordyline fruticosa } \\
\text { Cycas revoluta } \\
\text { Dracaena fragrans } \\
\text { Gardenia jasminoides } \\
\text { Rosa spp } \\
\text { Schefflera arboricola }\end{array}$ & $\begin{array}{l}\text { Devil's walking stick } \\
\text { Croton } \\
\text { Cordyline } \\
\text { Sago palm } \\
\text { Corn Plant } \\
\text { Gardenia } \\
\text { Rose } \\
\text { Schefflera } \\
\end{array}$ & كرون أراليا \\
\hline Trees & $\begin{array}{l}\text { Cupressus macrocarpa } \\
\text { Delonix regia } \\
\text { Ficus benjamina }\end{array}$ & $\begin{array}{l}\text { Italian cypress } \\
\text { Flamboyant } \\
\text { Ficus }\end{array}$ & سرو ليمونياني \\
\hline
\end{tabular}

*www.desert-tropicals.com/Plants/sci_names_D.html

* www.floridata.com/lists/contents.cfm?alphaLetter $=Z$

Nematode seasonal fluctuation:

Fluctuations of plant parasitic nematodes associated with 4 ornamental plant species (Schefflera, Dodonaea, Lantana and Window leaf) were conducted in a clay loam soil (coarse sand $17.8 \%$, fine sand $22.2 \%$, silt $20.0 \%$, clay $40.0 \%$, pH 8.2 and E.C. 10.9), weed-free area at Aquatic garden, Faculty of Agriculture, Cairo university, Giza Governorate. For it to work out the sampled plants were selected at random and labeled as permanent sampling sites. From each plant, a total of 3 soil sub-samples were taken at each sampling site to form a composite soil sample of $250 \mathrm{~g}$ each at $0-25 \mathrm{~cm}$ depth, were collected at monthly intervals for one year (Starting November, 2011 to October, 2012) by using manual auger. In all cases, the soil samples collected were in close contact with the plant roots. Soil temperature was recorded monthly at the sampling time by assistance of Soil Department, Faculty of Agriculture, Cairo University (Fig. 1). Soil samples were processed for nematode extraction by means of centrifugal-flotation technique (Jenkins, 1964) and counted using Hawksley counting slid. Population density of nematode genera was determined throughout the period of investigation. 


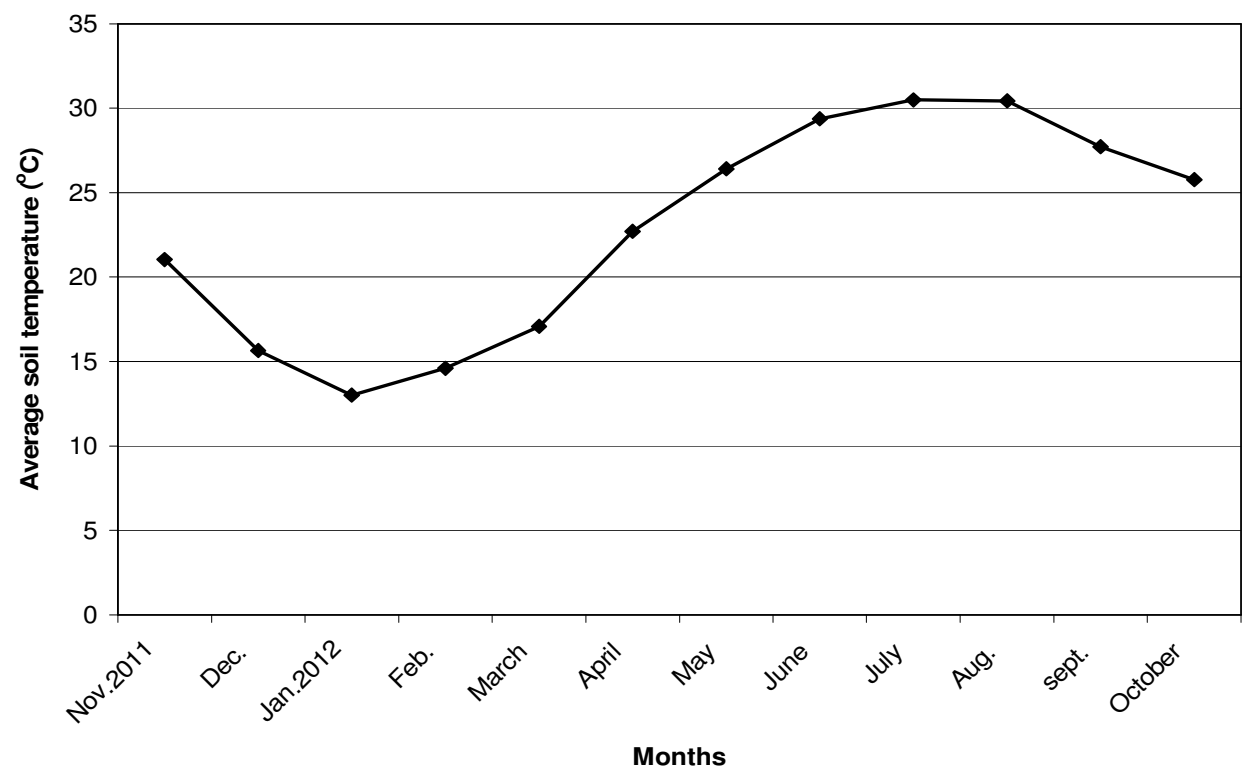

Fig. (1): Average soil temperature at sampling sites during November, 2011 to October, 2012.

\section{Results}

Data in table (2) reveal that 21 phytonematode genera were recovered from 909 soil samples collected from 15 ornamental plant species grown in five Egyptian governorates. The nematode genera, Criconemoides, Helicotylenchus and Rotylenchulus were the most prevalent in all surveyed localities ranging from high to low population density. Most nematode genera were recovered from nurseries and ornamental plantations of Cairo, Giza followed by Sharqia governorates. Only four genera, Criconemoides, Helicotylenchus, Pratylenchus and Rotylenchulus were detected in Qalyubia. Brachydorus and Scutellonema were recovered in Sharqia. Each of Criconema, Hemicriconemoides, Hemicycliophora, Ditylenchus and Heterodera were recovered from Cairo, Giza and Beheria, respectively.

With regard to the nematode distribution according to soil type (Table 3), sandy soils were rich in their infestation with nematode genera. The spiral, ring followed by reniform and root-knot nematodes distributed and populated highly in sandy soils. It is interesting to notice that the nematode genera Helicotylenchus, Hoplolaimus and Paratylenchus were recovered in high population density and frequencies of occurrence in peat samples. Meloidogyne and Rotylenchulus were rather low. Sandy soils were free from Aphelenchoides, Brachydorus, Ditylenchus and Tetylenchus. Sandy loam soils exhibited high levels of infestations and density of Criconemoides and Helicotylenchus. High to relatively low infestations with Helicotylenchus and Rotylenchulus were exhibited by clay soils. 
Table (2): Distribution, occurrence and density of plant par asitic nematodes encounter ed in differ ent ornamental locations.

\begin{tabular}{|c|c|c|c|c|c|c|c|c|c|c|}
\hline \multirow[t]{2}{*}{ Nematode Genera } & \multicolumn{2}{|c|}{$\begin{array}{c}\text { Beheira } \\
\text { (69) }\end{array}$} & \multicolumn{2}{|c|}{$\begin{array}{c}\text { Cairo } \\
(60)\end{array}$} & \multicolumn{2}{|c|}{$\begin{array}{l}\text { Giza } \\
(698)\end{array}$} & \multicolumn{2}{|c|}{$\begin{array}{c}\text { Qabyubia } \\
\text { (35) }\end{array}$} & \multicolumn{2}{|c|}{$\begin{array}{c}\text { Sharqia } \\
\text { (47) }\end{array}$} \\
\hline & P.D. & F.O. & P.D. & F.O. & P.D. & F.0. & P.D. & F.O. & P.D. & F.0. \\
\hline Aphelenchoides (Fischer, 1894) & 0 & 0 & 0 & 0 & 440 & 0.29 & 0 & 0 & 0 & 0 \\
\hline Brachydorus (de Guiran and Germani, 1968) & 0 & 0 & 0 & 0 & 0 & 0 & 0 & 0 & 550 & 2.13 \\
\hline Criconemoides (Tylor, 1936) & 1950 & 28.99 & 2710 & 35.00 & 522 & 0.86 & 544 & 14.29 & 0 & 0 \\
\hline Criconema (Hofmanner and Menzel, 1914) & 0 & 0 & 680 & 3.33 & 0 & 0 & 0 & 0 & 0 & 0 \\
\hline Ditylenchus (Filipjev, 1936) & 0 & 0 & 0 & 0 & 83 & 1.15 & 0 & 0 & 0 & 0 \\
\hline Helicotylenchus (Steiner, 1945) & 1087 & 8.70 & 952 & 35.00 & 897 & 23.21 & 230 & 2.86 & 8276 & 19.15 \\
\hline Hemicriconemoides (Chitwood and Birchfield, 1957) & 0 & 0 & 825 & 16.67 & 0 & 0 & 0 & 0 & 0 & 0 \\
\hline Hemicyclicphora (de Man, 1921) & 0 & 0 & 0 & 0 & 400 & 0.43 & 0 & 0 & 0 & 0 \\
\hline Heterodera (Schmidt, 187 1) & 300 & 2.90 & 0 & 0 & 0 & 0 & 0 & 0 & 0 & 0 \\
\hline Hopl daimus (Da day, 1905) & 0 & 0 & 563 & 20 & 1038 & 7.88 & 0 & 0 & 0 & 0 \\
\hline Longidorus (Filipjev, 1934) & 800 & 8.70 & 300 & 1.67 & 550 & 0.14 & 0 & 0 & 0 & 0 \\
\hline Meloidogyne (Göldi, 1892) & 1200 & 1.45 & 413 & 5.00 & 627 & 7.02 & 0 & 0 & 340 & 8.51 \\
\hline Paratylenchus (Micoletzky, 1922) & 0 & 0 & 165 & 1.67 & 4308 & 9.03 & 0 & 0 & 0 & 0 \\
\hline Pratylenchus (Filipjev, 1936) & 0 & 0 & 1087 & 13.33 & 374 & 3.58 & 310 & 5.71 & 575 & 4.28 \\
\hline Rotylenchulus (Linford and Oliveira, 1940) & 400 & 1.45 & 1320 & 3.33 & 634 & 12.18 & 914 & 17.14 & 1320 & 4.28 \\
\hline Scutellonema (Andrassy, 1958) & 0 & 0 & 0 & 0 & 0 & 0 & 0 & 0 & 1050 & 2.13 \\
\hline Tetylenchus (Filipjev, 1936) & 0 & 0 & 0 & 0 & 621 & 1.00 & 0 & 0 & 71 & 2.13 \\
\hline Tylenchorhynchus (Cobb, 1913) & 500 & 5.80 & 330 & 3.33 & 65 & 2.29 & 0 & 0 & 0 & 0 \\
\hline Tylenchuius (Cobb, 1913) & 0 & 0 & 0 & 0 & 400 & 0.29 & 0 & 0 & 0 & 0 \\
\hline Tylenchus (Bastian, 1865) & 0 & 0 & 495 & 3.33 & 186 & 1.58 & 0 & 0 & 242 & 6.38 \\
\hline Xiphinema (Cobb, 1913) & 400 & 1.45 & 0 & 0 & 386 & 2.01 & 0 & 0 & 560 & 2.13 \\
\hline
\end{tabular}

P.D. - Population densty (A bsolute density).

F.O. - Frequency occurence (ADsolute frequency) 
Table (3): Distribution, occurrence and density of plant parasitic nematodes encountered in different ornamental soil types.

\begin{tabular}{|c|c|c|c|c|c|c|c|c|c|c|c|c|}
\hline \multirow{2}{*}{$\begin{array}{l}\text { Nematode } \\
\text { Genera }\end{array}$} & \multicolumn{3}{|c|}{$\begin{array}{c}\text { Sandy } \\
(395)\end{array}$} & \multicolumn{3}{|c|}{$\begin{array}{c}\text { Sandy loam } \\
\text { (127) }\end{array}$} & \multicolumn{3}{|c|}{$\begin{array}{l}\text { Clay } \\
(185) \\
\end{array}$} & \multicolumn{3}{|c|}{$\begin{array}{l}\text { Peat } \\
(202) \\
\end{array}$} \\
\hline & P.D. & F.O. & R.F. & P.D. & F.O. & R.F. & P.D. & F.O. & R.F. & P.D. & F.O. & R.F. \\
\hline Aphelenchoides & 0 & 0 & 0 & 220 & 1.57 & 2.70 & 88 & 0.54 & 0.64 & 0 & 0 & 0 \\
\hline Brachydorus & 0 & 0 & 0 & 550 & 0.79 & 1.35 & 0 & 0 & 0 & 0 & 0 & 0 \\
\hline Criconemoides & 2264 & 10.94 & 16.83 & 1360 & 1.57 & 2.70 & 396 & 3.24 & 3.82 & 0 & 0 & 0 \\
\hline Criconema & 660 & 0.51 & 0.78 & 0 & 0 & 0 & 0 & 0 & 0 & 0 & 0 & 0 \\
\hline Ditylenchus & 0 & 0 & 0 & 0 & 0 & 0 & 122 & 2.16 & 2.54 & 44 & 1.98 & 2.28 \\
\hline Helicotylenchus & 618 & 15.01 & 23.10 & 1793 & 37.01 & 63.51 & 1189 & 16.22 & 19.08 & 1075 & 31.19 & 35.85 \\
\hline Hemicriconemoides & 825 & 2.54 & 3.91 & 0 & 0 & 0 & 0 & 0 & 0 & 0 & 0 & 0 \\
\hline Hemicycliophora & 400 & 0.76 & 1.17 & 0 & 0 & 0 & 0 & 0 & 0 & 0 & 0 & 0 \\
\hline Heterodera & 300 & 0.51 & 0.78 & 0 & 0 & 0 & 0 & 0 & 0 & 0 & 0 & 0 \\
\hline Hoplolaimus & 136 & 4.58 & 7.05 & 120 & 3.15 & 5.41 & 68 & 0.54 & 0.64 & 1289 & 20.30 & 23.33 \\
\hline Longidorus & 807 & 1.78 & 2.74 & 0 & 0 & 0 & 0 & 0 & 0 & 0 & 0 & 0 \\
\hline Meloidogyne & 111 & 7.12 & 10.96 & 0 & 0 & 0 & 61 & 4.86 & 5.72 & 106 & 8.42 & 9.67 \\
\hline Paratylenchus & 444 & 2.04 & 3.13 & 0 & 0 & 0 & 339 & 4.32 & 5.09 & 5660 & 23.27 & 26.74 \\
\hline Pratylenchus & 168 & 4.83 & 7.44 & 442 & 3.15 & 5.41 & 273 & 8.11 & 9.54 & 0 & 0 & 0 \\
\hline Rotylenchulus & 639 & 7.89 & 12.14 & 811 & 7.09 & 12.16 & 631 & 28.65 & 33.70 & 53 & 1.98 & 2.28 \\
\hline Scutellonema & 1000 & 0.25 & 0.39 & 1050 & 0.79 & 1.35 & 0 & 0 & 0 & 0 & 0 & 0 \\
\hline Tetylenchus & 0 & 0 & 0 & 511 & 0.79 & 1.35 & 635 & 3.24 & 3.82 & 0 & 0 & 0 \\
\hline Tylenchorhynchus & 362 & 2.29 & 3.52 & 330 & 2.36 & 4.05 & 358 & 4.86 & 5.72 & 0 & 0 & 0 \\
\hline Tylenchulus & 400 & 0.51 & 0.78 & 0 & 0 & 0 & 0 & 0 & 0 & 0 & 0 & 0 \\
\hline Tylenchus & 339 & 1.02 & 1.57 & 0 & 0 & 0 & 303 & 4.32 & 5.09 & 0 & 0 & 0 \\
\hline Xiphinema & 467 & 2.29 & 3.52 & 0 & 0 & 0 & 170 & 3.24 & 3.82 & 0 & 0 & 0 \\
\hline
\end{tabular}


Data on the population and frequency of occurrence of stylet bearing nematode genera associated with different ornamental species are shown in tables 4 \& 5. Data indicate that 15 genera were recovered from Paspalum 10 Criconemoides, Helicotylenchus, Pratylenchus and Rotylenchulus were found to be the most nematode genera inhabiting paspalum rhizosphere. Helicotylenchus, Rotylenchulus, Tetylenchus and Tylenchorhynchus were the dominant on trees, Italian cypress, Ficus and Flamboyant. Paratylenchus was found in high population and frequency of occurrence on Ficus. Aphelenchoides and Brachydorus were recovered only from Italian cypress samples.

The perennials sampled were poor in their infestation with phyto-nematodes. The ring and reniform nematodes were abundant in chrysanthemum samples while the root-knot occurred in $66 \%$ of golden rod samples with high population density. $20 \%$ of Pothos samples were infested with Meloidogyne in relatively high density. Paratylenchus was also, found in low occurrence.

In shrubs, spiral and lance nematodes occurred in more than $50 \%$ of Brassica samples with relatively high population density, followed by reniform and root-knot nematodes. The root knot was recovered from $32 \%$ of Devil's walking stick samples. The dagger nematode occurred in $19 \%$ of sago palm samples with rather low population density followed by lance nematode. $73 \%$ of corn plant samples were infested with the reniform nematode in moderate population density. Aphelenchoides, Criconemoides and Tylenchorhynchus were found in very low infestation levels in rose samples. More than $50 \%$ of croton samples contained Paratylenchus with very high population density followed by Pratylenchus with $10 \%$ frequency of occurrence and rather low density. Almost $10 \%$ of gardenia samples were infested with Meloidogyne in rather high density followed by the spiral and dagger nematodes.

Temporal dynamics of four plant parasitic nematode genera encountered on four ornamental shrub species grown in one site of non-disturbed clay loam soil in a garden located at faculty of agriculture at Giza were determined in monthly intervals starting in November 2011 to October 2012. Nematode diversity and the population dynamics of Criconemoides, Helicotylenchus, Hoplolaimus and Rotylenchulus were estimated inclusive together with monthly recording of soil temperature.

Data as shown in Figs. (2, 3, 4 \& 5) indicate that the nematodes populations varied widely according to host type and nematode genera during the investigation period. Despite variation in temperature and host type on which seasonal fluctuations mainly depend, nearly all the nematode populations studied remained active in varying degrees during the year. The nematode population had at least two peaks and two drops in their soil populations which were more or less correlated with soil temperature and surely with host compatibility.

The ring nematode, Criconemoides peaked in November on Schefflera and sharply decreased in December up to May where a slight increase was recorded then a gradual decrease to September. Criconemoides population increased 
Table (4): Distribution, occurrence and dens ity of plant parasitic nematodes encountered in s ome perennials, trees and lawns.

\begin{tabular}{|c|c|c|c|c|c|c|c|c|c|c|c|c|c|c|}
\hline \multirow{3}{*}{ Nematode Genera } & \multicolumn{6}{|c|}{ Perennials } & \multicolumn{6}{|c|}{ Trees } & \multicolumn{2}{|c|}{ Lawns } \\
\hline & \multicolumn{2}{|c|}{ Pothos } & \multicolumn{2}{|c|}{ Goldenrod } & \multicolumn{2}{|c|}{ Chrysanthemum } & \multicolumn{2}{|c|}{ Italian cypress } & \multicolumn{2}{|c|}{ Ficus } & \multicolumn{2}{|c|}{ Flamboyant } & \multicolumn{2}{|c|}{ Paspalum 10} \\
\hline & P.D & F.O. & P.D & F.O. & P.D & F.O. & P.D & F.O. & P.D & F.O. & P.D & F.O. & P.D & F.O. \\
\hline Aphelenchoides & 0 & 0 & 0 & 0 & 0 & 0 & 880 & 1.37 & 0 & 0 & 0 & 0 & $\overline{0}$ & 0 \\
\hline Brachydonus & 0 & 0 & 0 & 0 & 0 & 0 & 550 & 1.37 & 0 & 0 & 0 & 0 & 0 & 0 \\
\hline Criconem cides & 0 & 0 & 0 & 0 & 844 & 7.58 & 0 & 0 & 240 & 0.93 & 330 & 10.53 & 2353 & 25.63 \\
\hline Criconema & 0 & 0 & 0 & 0 & 0 & 0 & 0 & 0 & 0 & 0 & 0 & 0 & 680 & 1.25 \\
\hline Ditylenchus & 0 & 0 & 0 & 0 & 0 & 0 & 122 & 5.48 & 0 & 0 & 0 & 0 & 0 & 0 \\
\hline Helic otylenchus & 0 & 0 & 0 & 0 & 0 & 0 & 1717 & 61.64 & 1851 & 63.55 & 457 & 15.79 & 929 & 23.75 \\
\hline Hemicriconemoides & 0 & 0 & 0 & 0 & 0 & 0 & 0 & 0 & 0 & 0 & 0 & 0 & 825 & 6.25 \\
\hline Heterodera & 0 & 0 & 0 & 0 & 0 & 0 & 0 & 0 & 0 & 0 & 0 & 0 & 200 & 1.88 \\
\hline Hoplolaimus & 0 & 0 & 0 & 0 & 0 & 0 & 0 & 0 & 490 & 9.53 & 0 & 0 & 563 & 7.5 \\
\hline Longidonus & 0 & 0 & 0 & 0 & 0 & 0 & 0 & 0 & 0 & 0 & 0 & 0 & 706 & 5 \\
\hline Meloidogyne & 500 & 20 & 1740 & 68.67 & 0 & 0 & 0 & 0 & 191 & 6.54 & 0 & 0 & 598 & 3.13 \\
\hline Paratylenchus & 300 & 6.67 & 0 & 0 & 0 & 0 & 0 & 0 & 1411 & 18 & 0 & 0 & 185 & 0.63 \\
\hline Pratylenchus & 0 & 0 & 0 & 0 & 0 & 0 & 0 & 0 & 421 & 5.6 & 0 & 0 & 818 & 8.75 \\
\hline Rotylenchulus & 0 & 0 & 0 & 0 & 735 & 3.03 & 720 & 1.37 & 412 & 7.47 & 1173 & 31.6 & 693 & 5.63 \\
\hline Scutellonema & 0 & 0 & 0 & 0 & 0 & 0 & 1050 & 1.37 & 0 & 0 & 0 & 0 & 100 & 0.63 \\
\hline Tetylenchus & 0 & 0 & 0 & 0 & 0 & 0 & 769 & 5.48 & 257 & 2.8 & 575 & 5.3 & 0 & 0 \\
\hline Tylenchorhynchus & 0 & 0 & 0 & 0 & 0 & 0 & 110 & 1.37 & 379 & 3.73 & 362 & 26.32 & 462 & 5 \\
\hline Tylenchus & 0 & 0 & 0 & 0 & 0 & 0 & 272 & 5.48 & 241 & 1.87 & 0 & 0 & 339 & 2.5 \\
\hline Xiphinema & 0 & 0 & 0 & 0 & 0 & 0 & 0 & 0 & 393 & 1.87 & 0 & 0 & 400 & 0.63 \\
\hline
\end{tabular}

P.D. - Population densty (A bsolute densiny).

F.O Frequency occurrence (Absolute frequency). 
Table (5): Distribution, occurrence and dens ity of plant par as itic nematodes encounter ed in s ome shrubs.

\begin{tabular}{|c|c|c|c|c|c|c|c|c|c|c|c|c|c|c|c|c|}
\hline \multirow{3}{*}{ Nematode Genera } & \multicolumn{16}{|c|}{ Shrubs } \\
\hline & \multicolumn{2}{|c|}{ Brassaia } & \multicolumn{2}{|c|}{ Sago paim } & \multicolumn{2}{|c|}{$\begin{array}{c}\text { Devil s } \\
\text { walking stick }\end{array}$} & \multicolumn{2}{|c|}{ Com Plant } & \multicolumn{2}{|c|}{ Rose } & \multicolumn{2}{|c|}{ Croton } & \multicolumn{2}{|c|}{ Cordyline } & \multicolumn{2}{|c|}{ Gardenia } \\
\hline & P.D & F.O. & P.D & F.O. & P.D & F.O. & P.D & F.O. & P.D & F.O. & P.D & F.O. & P.D & F.O. & P.D & F.O. \\
\hline Aphelenchoides & 0 & 0 & 0 & 0 & 0 & 0 & 0 & 0 & 88 & 1.52 & 0 & 0 & 0 & 0 & 0 & 0 \\
\hline Ciconemoides & 162 & 1.6 & 0 & 0 & 0 & 0 & 0 & 0 & 22 & 1.61 & 0 & 0 & 0 & 0 & 0 & 0 \\
\hline Ditylenchus & 44 & 6.45 & 0 & 0 & 0 & 0 & 0 & 0 & 0 & 0 & 0 & 0 & 0 & 0 & 0 & 0 \\
\hline Helicotylenchus & 614 & 51.61 & 0 & 0 & 220 & 4 & 0 & 0 & 0 & 0 & 0 & 0 & 400 & 23.81 & 600 & 4.55 \\
\hline Hemicycliophora & 0 & 0 & 0 & 0 & 0 & 0 & 0 & 0 & 0 & 0 & 400 & 4.62 & 0 & 0 & 0 & 0 \\
\hline Hopl daimus & 480 & 54.83 & 256 & 11.36 & 0 & 0 & 119 & 7.7 & 0 & 0 & 0 & 0 & 0 & 0 & 0 & 0 \\
\hline Meloidogyne & 201 & 20.97 & 0 & 0 & 715 & 32 & 80 & 3.84 & 0 & 0 & 0 & 0 & 0 & 0 & 725 & 9.09 \\
\hline Paratylenchus & 720 & 1.81 & 0 & 0 & 0 & 0 & 50 & 3.84 & 0 & 0 & 6717 & 55.38 & 0 & 0 & 0 & 0 \\
\hline Pratylenchus & 0 & 0 & 0 & 0 & 0 & 0 & 0 & 0 & 331 & 9.52 & 457 & 10.77 & 330 & 4.76 & 0 & 0 \\
\hline Rotylenchulus & 823 & 25.8 & 0 & 0 & 0 & 0 & 484 & 73.07 & 0 & 0 & 286 & 4.62 & 417 & 28.57 & 0 & 0 \\
\hline Tylenchorhynchus & 110 & 1.61 & 0 & 0 & 0 & 0 & 0 & 0 & 88 & 2.38 & 0 & 0 & 0 & 0 & 0 & 0 \\
\hline Tylenchulus & 0 & 0 & 400 & 4.55 & 0 & 0 & 0 & 0 & 0 & 0 & 0 & 0 & 0 & 0 & 0 & 0 \\
\hline Tylenchus & 300 & 3.22 & 0 & 0 & 0 & 0 & 0 & 0 & 0 & 0 & 0 & 0 & 0 & 0 & 0 & 0 \\
\hline Xiphinema & 162 & 1.61 & 400 & 3.64 & 0 & 0 & 45 & 3.84 & 0 & 0 & 0 & 0 & 50 & 4.76 & 800 & 2.27 \\
\hline
\end{tabular}

P. D. - Population densty (absolute density).

F.O Frequency occurrence (ab solute frequency)- 
sharply depicting highest values in October reaching its second peak. Dodonaea seems to be incompatible host to ring nematode where it recorded low populations most of the year except November its population was relatively moderate.

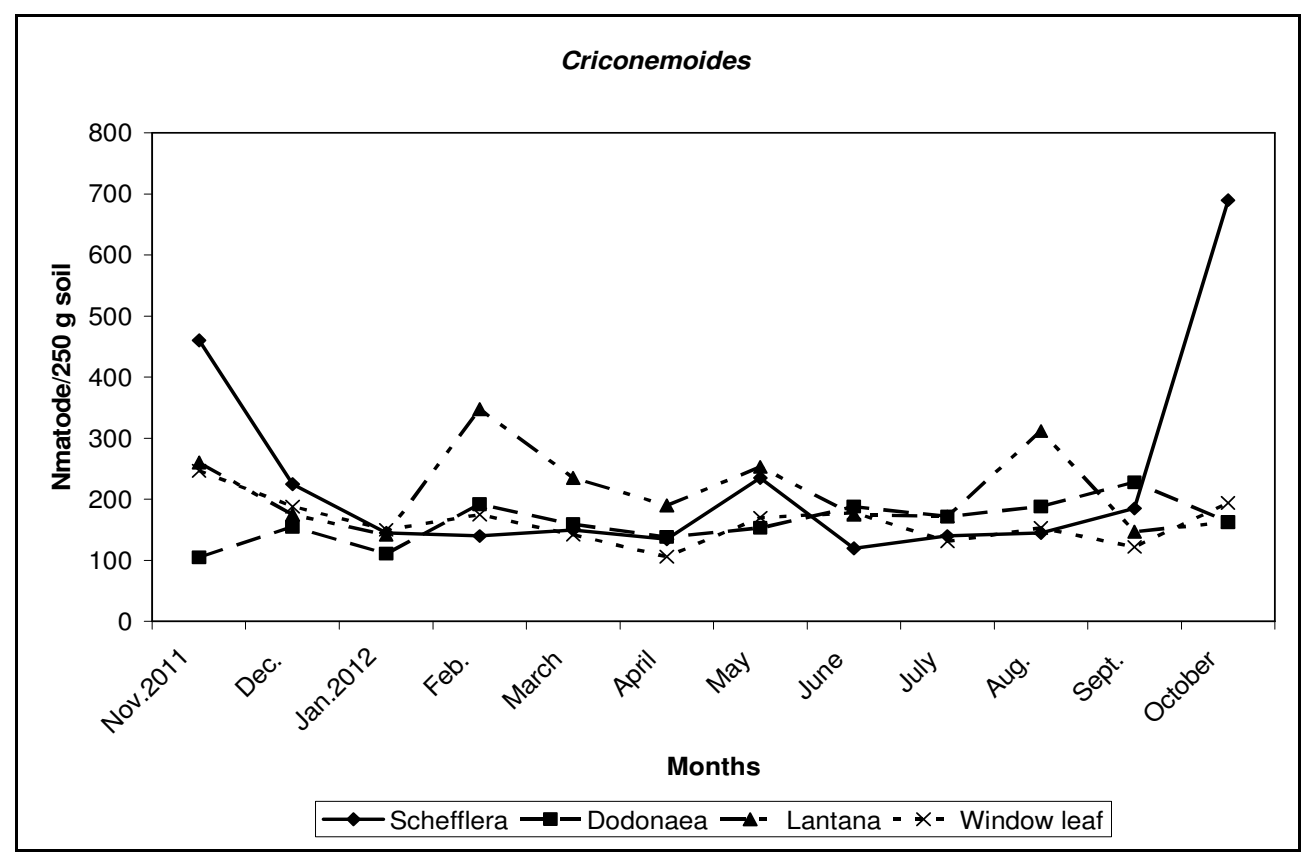

Fig. (2): Criconemoides seasonal population changes on four ornamental plants.

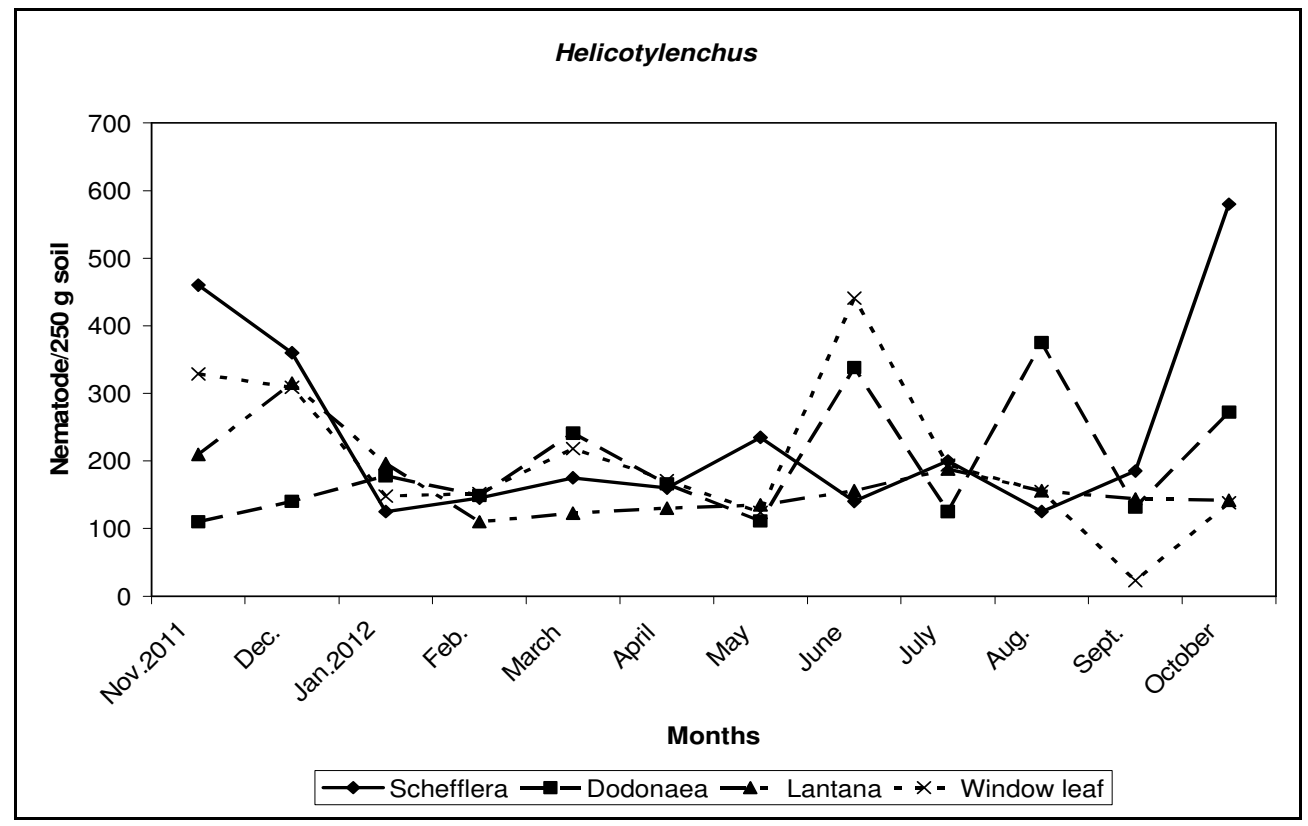

Fig. (3): Helicotylenchus seasonal population changes on four ornamental plants. 


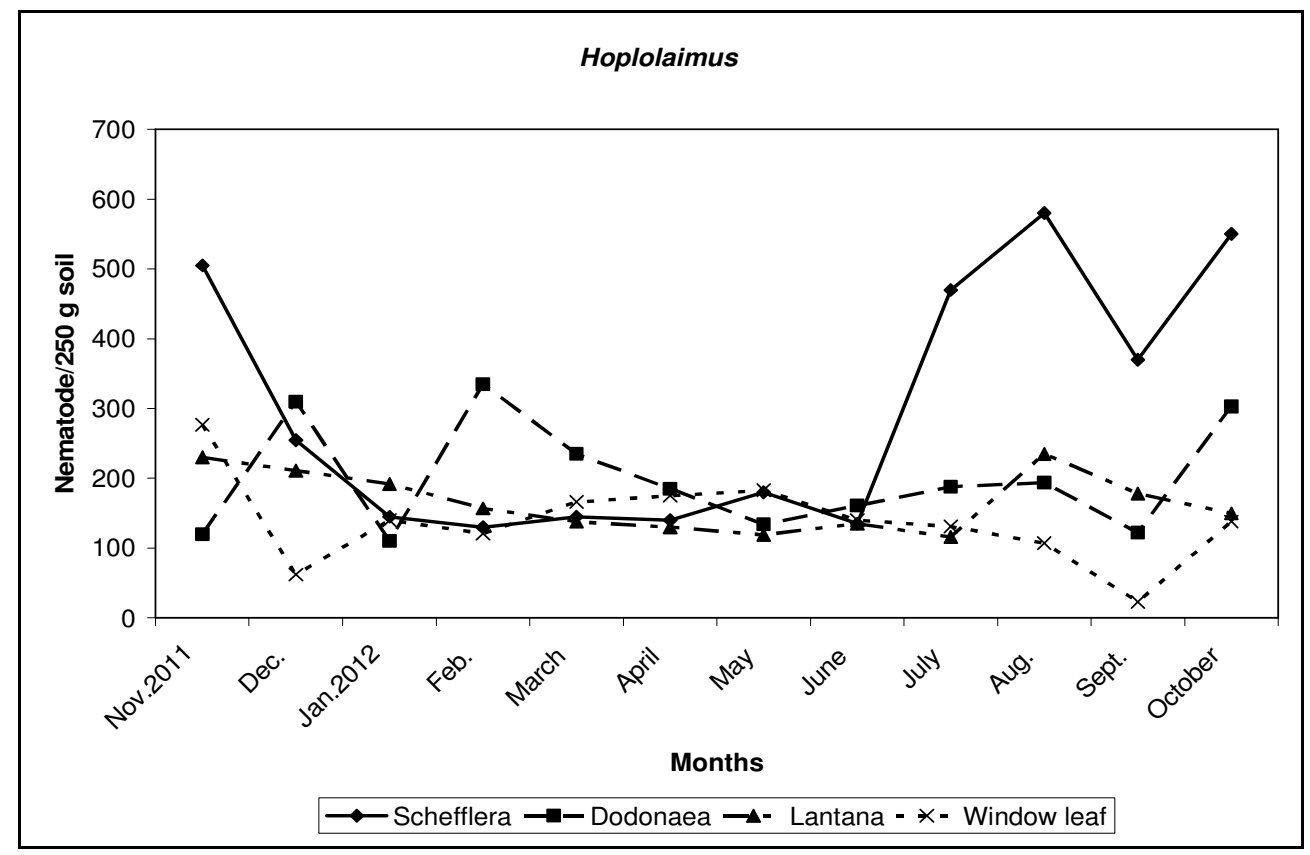

Fig. (4): Hoplolaimus seasonal population changes on four ornamental plants.

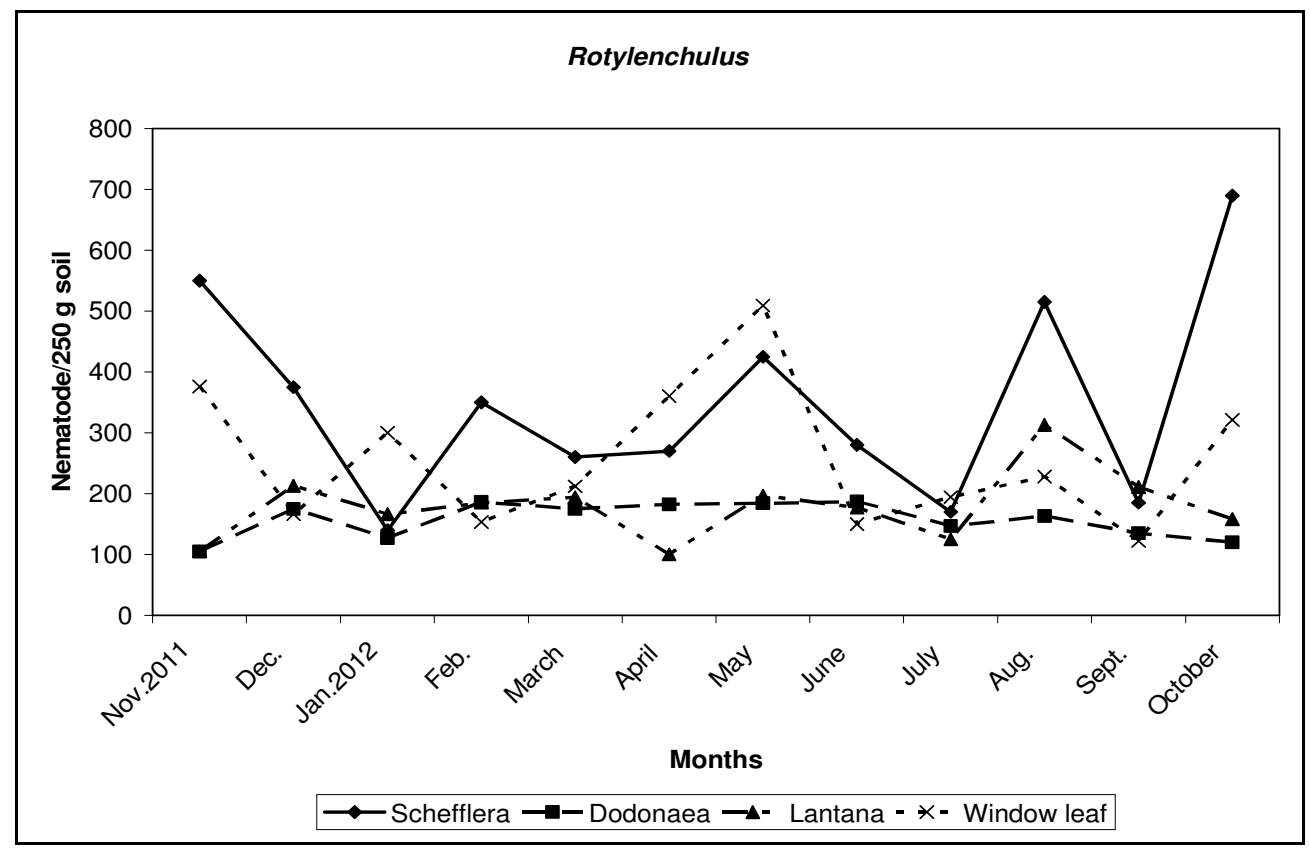

Fig. (5): Rotylenchulus seasonal population changes on four ornamental plants. 
On Lantana ring nematode peaked in February and August and fluctuated from March to July. The nematode was active during October and November and populated highly, there after a gradual decrease till April and slight increase in May and June on Window leaf.

The spiral nematode, Helicotylenchus soil population varied markedly and found in considerable density in November on Schefflera and window leaf then decreased sharply in January. The spiral nematode achieved its second peak on window leaf in June and in October on Schefflera. Two noticeable minima in spiral nematode population in May and September on window leaf. The nematode behaved differently on Dodonaea where its population increased steadily from March to April. The nematode density dropped in May, July and September and achieved two peaks in June and August. The spiral nematode population raised on Lantana during November-December, then decreased sharply in January and February, a gradual but slight increase from March up to July. It reached its highest level in December.

The lance nematode, Hoplolaimus populated highly in November on Schefflera then curtailed sharply in the subsequent three months. A slight increase was noticed in spring months. A remarkable increase was observed in July and more numerous were recorded in August. A relapse in nematode population was detected in September. A month later, the nematode population recorded its second peak. On Dodonaea, the lance nematode achieved three moderate peaks in December, February and October, and three drops in November, January and September. A gradual decline in nematode population from March to May then steady increase as soil temperature increase in the three subsequent months.

On window leaf the nematode recorded two sharply drops in December and September. A rise in nematode population during spring and gradual decrease in summer months were obvious. The nematode population was activated by October and a moderate peak was obtained by November. Lantana seems to be unfavorable host to Hoplolaimus, the nematode population decline gradually from December to July. One moderate peak was detected from samples collected in August. The reniform nematode, $R$. reniformis population density is strongly influenced by soil temperature and host type. Schefflera maintained the nematode densities at high levels at the end of the season (October-November). Nematode abundance declined rapidly by January. Three gradual peaks with more numerous densities were recorded in February, May and August. Nematode density reached its maxima in October. On window leaf the nematode behaved differently, lowest nematode numbers were recorded in December, February, June and September. Highest peak was reported in May. A steady increase was observed in October and November. On Dodonea almost constant density was observed from February to June, there after a gradual decline in population occurred towards the end of the season. Lantana supported the reniform population poorly, a moderate rise was recorded in August and lowest numbers were recovered in April. 


\section{Discussion}

Many ornamentals (perennials, lawns, shrubs and trees) are listed as hosts to phytonematofauna with various degrees of infestation all over the world (Jagirdar, 2005; Deimi et al., 2008; Brito et al., 2010 and El-Sherbiny, 2011). Our results indicate that the surveyed nurseries and ornamental plantations in 4 governorates in Egypt are subjected to attack by 21 phytonematode genera Aphelenchoides, Brachydorus, Criconemoides, Criconema, Ditylenchus, Helicotylenchus, Hemicriconemoides, Hemicycliophora, Heterodera, Hoplolaimus, Longidorus, Meloidogyne, Paratylenchus, Pratylnchus, Rotylenchulus, Scutellonema, Tetylenchus, Tylenchorhynchus, Tylenchus and Xiphinema. Their frequencies of occurrence and population densities were variable according to locality, soil and host types. Nurseries and ornamental plantations of Cairo and Giza registered most of the nematode genera recorded. The nematode genera Criconemoides, Helicotylenchus, Rotylenchulus and Scutellonema were the most dominating in areas of sandy and sandy loam soils. At Beheria governorate, a sandy soil area, recorded Criconemoides, Helicotylenchus, Longidorus and Meloidogyne in common association with ornamentals. As the soil lighten, the nematode genera diverse. Spiral and reniform nematodes achieved the highest frequencies of occurrence and population densities in areas of clay soils. No wonder that peat samples were infested with Helicotylenchus, Hoplolaimus and Paratylenchus in highly abundance and density. It is interesting that the spiral nematode was the most dominant in all soil types. However, the surveyed perennials were poor in their infestation with nematode genera, pothos and golden rod were highly infested with the root-knot nematode. Criconemoides and Rotylenchulus were the only genera recovered in chrysanthemum samples. The nematode genera, Helicotylenchus, Rotylenchulus, Tylenchorhynchus and Tetylenchus were in common association with ornamental trees (Italain cypress, Ficus and Flamboyant). The landscapes (Paspalum 10) samples were the richest and recorded 15 nematode genera. Criconemoides, Helicotylenchus, Hemicriconemoides, Pratylenchus and Rotylenchulus were the most abundant. Nematode genera abundance and density were variable in shrubs; Hoplolaimus, Helicotylenchus, Rotylenchulus and Meloidogyne were high in their frequency of occurrence on Schefflera, Hoplolaimus and Xiphinema on sago palm, Meloidogyne on Devil's walking stick, Rotylenchulus on corn plant, Pratylenchus and Paratylenchus on croton, Helicotylenchus and Rotylenchulus on cordyline and Meloidogyne on gardenia. Our results confirm that occurrence diversity of P.P.N. recovered by many environmental conditions, soil type and host species in particular. Our result were coming along to great extent with those of Ahuja and Arora 1980; Al-Sayed 1983; Tenete 1996; Khan et al., 1997; Chandel et al., 1997; Ditimiet et al., 2008; Brito et al., 2010; Chatansk and Skwircs, 2011 and El-Sherbiny 2011.

A study on nematode population dynamics of the most abundant nematode 
genera recorded on four shrubs species grown in clay loam soil was carried out starting from November 2011 to October 2012. We infer from our data that the nematode dynamics related to soil temperature and host plant species and there were recognizable high and low seasonal patterns. There were apparent differences of each nematode population on the four hosts and this may attributable to how much compatible or incompatible each host to each nematode population.

High population values of Criconemoides were recorded on Schefflera and window leaf in November, Declined in December and fluctuated up to achieve lowest values in April and moved up again in May. However, highest density was found in October, less values of increase were observed on window leaf. On Lantana, three moderate peaks were recorded in February, May and August. It seems that Dodonaea was incompatible host despite a slight gradual increase from May to September was noticed.

The spiral nematode acted differently and soil temperature influence was noticeable. An increase in numbers of nematode was corresponded by increase in soil temperature. Helicotylenchus peaked during June on Dodonaea and window leaf and peaked again on the later in August. Highest values of spiral nematode populations were found at the end of the season. Low numbers were recorded on lantana in November, increased to January, dropped in February and a steady slight increase from March to July then declined again up to October. Al-Sayed 1983 reported that Helicotylenchus increased gradually on Jasmine as soil temperature increase and reached to remarkable peak in May and July. Pinochet and Cisneros 1986 noticed maximum increase of Helicotylenchus during summer months on grape.

The lance nematode populated highly on Schefflera, Dodonaea and window leaf in October and November but in different degrees. Low numbers were recorded on the three hosts in September. Two moderate peaks were noticed on Dodonaea in winter months. Two noticeable drops were observed on window leaf during December and September. Acute fluctuation of the reniform nematode population was recognized according to soil temperature. Schefflera showed more or less similar pattern to that of window leaf. Schefflera was more compatible to $R$. reniformis than window leaf. $R$. reniformis peaked on the two hosts in May when the temperature rise above $30 \stackrel{\circ}{\mathrm{C}}$ and related to high precipitation months of Autumn (October-November). The opposite was found on Lantana and Dodonaea, where the low population values were recorded in autumn (October-November). The reniform nematode peaked twice during June and October on Jasmine (Al-Sayed, 1983) highest nematode counts were frequently accompanied by high soil temperature and vice versa.

The nematode soil population fluctuations are inversely or positively related to several biotic and abiotic factors such as soil temperature, rainfall, soil structure, 
organic substances, microflora, management practices, soil depth, soil moisture, soil $\mathrm{pH}$, soil root interaction, growth and distribution of host roots during growing season (Siddiqi, 1963; Bakonyi and Nagy, 2000; Neher et al., 2004; McGroary, 2009; Fajardo et al., 2011 and Gantait and Bhattacharya, 2013) we add nematode plant compatibility, nematode species and nature of nematode parasitism.

\section{References}

Ahuja, S. and Arora, J.S. (1980). Susceptibility of flowering annuals to root-knot nematode (Meloidogyne incognita). Journal of Tropical Pest Management, 26(3):293-295.

Al-Sayed, A.A. (1983). Ecological and biological studies on the root-knot and reniform nematodes infecting Jasminum grandiflorum and Gladiolus sp. Ph.D. Thesis, Fac.Agric., Cairo Univ., 171 pp.

Bakonyi, G. and Nagy, P. (2000). Temperatures and moisture-induced changes in the structure of the nematode fauna of a semiarid grassland-patterns and mechanism. Global Change Biology, 6:697-707.

Brezeski, M.W.; Kotlinski, S. and Zepp, A.L. (1979). Observations on the pathogenicity of some nematodes for ornamental plants. Helminthological Abstracts, 48(1):1979.

Brito, J.A.; Kaur, R.; Cetintas, R.; Stanley, J.D.; Mendes, M.L.; Powers, T.O. and Dickson, D.W. (2010). Meloidogyne spp. infecting ornamental plants in Florida. Nematropica, 40(1):87-103.

Chandel, S. S.; Khanna, A.S. and Khan, M.L. (1997). Faunistic studies on nematodes associated with Gladiolus hortulanus L. Annals of Applied Agricultural Ressearch, 18(1):44-47.

Chatanska, A. and Skwiercz, A. (2011). Parasitic Nematodes on Polish Tulip Plantations. Journal of Plant Protection Research, 51(1):66-71.

Deimi, A.M.; Chitambar, J.J. and Maafi, Z.T. (2008). Nematodes associated with flowering ornamental plants in Mahallat, Iran. Nematologia Mediterranea, 36:115-123.

El-Sherbiny, A.A. (2011). Phytoparasitic Nematodes Associated with Ornamental Shrubs, Trees and Palms in Saudi Arabia, Including New host Records. Pakistan Journal of Nematology, 29(2):147-164.

Fajardo, P.M.; Aballay, E. and Casanova, P.M. (2011). Soil properties influencing phytoparasitic nematode population on Chilean vineyards. Chilean Journal of Agricultural Research, 71(2): 240-248. 
Gantait, V.V. and Bhattacharya, T. (2013). Community structure and population fluctuation of soil and plant parasitic nematodes in a Banana plantation of west Bengal. The Ecoscan (Special issue), 3:179-189.

Hooper, D.J.; Hallmann, J. and Subbotin, S.A. (2005). Methods for extraction, processing and detection of plant and soil nematodes. In: Plant Parasitic Nematodes in Subtrobical and Tropical Agriculture, pp. 53-86 (ed. Luc, M.; Sikora, R.A. and Bridge, J.). CABI publishing, Wallingford, UK.

Jagirdar, S.A. (2005). Studies on plant parasitic nematodes associated with polyhouse crops. M.Sc. Thesis, Agric. College, Dharwad Univ. of Agric. sciences. 48 pp.

Jenkis, W.R. (1964). A rapid centrifugal flotation technique for separating nematode from soil. Plant Disease Reporter, 48:692.

Kesba, H.H. (1999). Ecological and pathological studies on some plant parasitic nematodes infecting grape, Vitis vinifera L. M.Sc. Thesis, Fac. of Agric., Cairo Univ, Egypt, 114 pp.

Khan, S.A.; Qamar, F.; Khan, H.A.; Shakir, M.A. and Askari, A. (1997). Plant parasitic nematodes associated with floricultural crops in nurseries of Karachi and their control. Bangladesh Journal of Scientific and Industrial Research, 32:422-426.

Khanna, A.S. and Khan, M.L. (1990). Nematode associated with some ornamental plants in India. International Nematology Network Newsletter, 7:28-29.

Kim, J. I.; Choi, D.R.; Han, S.C. and Park, J.S. (1987). Survey of plant parasitic nematodes in fields growing ornamental plants and medicinal herbs. Research Report, RDA, Suwon, Republic of Korea 29:124-129.

Kinshakova, E.I. (1968). Gall nematodes in lower Volga area. Helminthological Abstracts, 43(1):1974.

Mai, W.F. and Lyon, H.H. (1975). Pictorial key to genera of Plant Parasitic nematodes $4^{\text {th }}$ Ed., Cornell University Press, Ithaca, NY., 219 p.

McGroary, P.; Crow, W.T.; Mc Sorley, R.; Giblin-Davis, R.M. and Cisar, J.L. (2009). Seasonal fluctuations of Belonolaimus longicaudatus in bermudagrass. Nematropica, 39(1):99-110.

Ministry of Agriculture (2013). www.agr-egypt.gov.eg/Uploads/Studies. Arabic reports.

Nagesh, M. and Reddy, P.P. (2000). Crop loss estimation in carnation and gerbera due to the root-knot nematode, Meloidogyne incognita (Kofoid \& White) Chitwood. Pest Management in Horticultural Ecosystems, 6: 158-159. 
Neher, D.A.; Wu, J.; Barbercheck, M.E. and Anas, O. (2004). Ecosystem type affects interpretation of soil nematode community measures. Appl. Soil Ecol., 30:47-64.

Norton, D.C. (1978). Ecology of Plant Parasitic Nematodes. John Wiley and Sons, New York, USA, 268 pp.

Pinochet, J. and Cisncros, T. (1986). Seasonal fluctuation of nematode population in three Spanish vineyards. Revue de Nematologie, 9:391-393.

Renco, M.; Liskova, M. and Cerevkova, A. (2010). Seasonal fluctuations of the nematode communities in a hop garden soil. Helminthologica, 47(2):115122.

Saka, V.W. and Siddiqi, M.A. (1979). Plant-parasitic nematodes associated with plants in Malawi. J. of Plant Disease Reporter, 63(11):945-948.

Sen, K. and Dasgupta, M.K. (1977). Additional hosts of the root-knot nematode, Meloidogyne spp. from India. Indian J. of Nematology, 7(1):74-77.

Siddiqi, M.R. (1963). Distribution of the nematode parasites of citrus in Uttar Pradesh. Labdev. J. Sci. Tech., 1:51-52.

Singh, R.V. and Sharma, H.K (1998). Nematode problems and their management in ornamental crops. In: Nematode Diseases in Plants (ed. Trivedi, P.C.) CBS Publishers and Distributors, New Delhi, pp. 168-176.

Streu, H.T.; Jenkins, W.R. and Hutchinson, M.T. (1961). Nematodes associated with carnations, Dianthus caryophyllus with special references to the parasitism and biology of Criconemoides curvatum. Bulletin of New Jersey Agricultural Experiment Station, 800, 32 pp.

Tenete, R.C.V. (1996). Nematode problems of Bulbs, with Special Reference to Ditylenchus dipsaci. Nematropica, 26:91-99. 


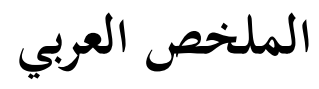

$$
\text { التركيب المجتمعي وديناميكية نيماتودا النبات على نباتات الزينة في مصر المبوات المعاطي السيد، عبدالله علي عبدالرحمن ، حسني حامد كسبه }
$$

في دراسة حصرية تبين وجود |ץ جنس Criconemoides, Brachydorus, Aphelenchoides, ,Helicotylenchus, Hemicriconemoides, Criconema, Ditylenchus Hemicycliophora, Heterodera, Hoplolaimus, Longidorus, Meloidogyne, Paratylenchus, Pratylenchus, Rotylenchulus, Scutellonema, Tetylenchus, Tylenchorhyncus, Tylenchulus, Tylenchus, Xiphinema زراعات نباتات الزينة في خمس محافظات مصرية، وقد تبين أن التنوع في المجتمع النيماتودي وكثافنه كان

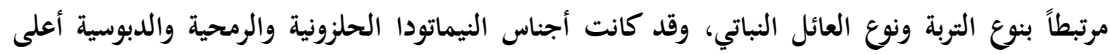

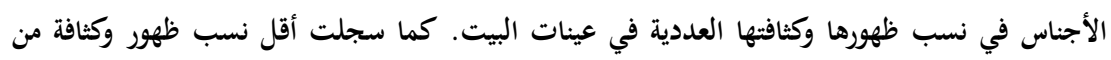

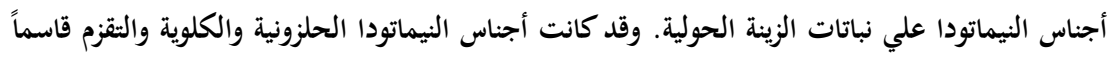

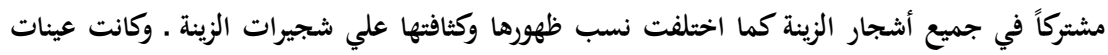
النجيل أغناها بأجناس النيماتودا وكثافتها العددية.

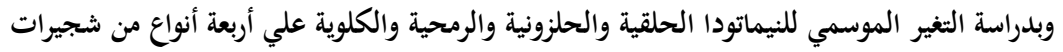

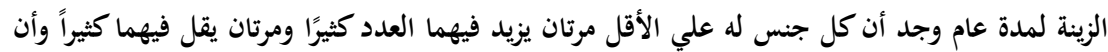

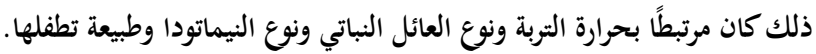

